\title{
Широкополосные быстродействующие полупроводниковые зеркала для пассивной синхронизации мод лазеров ближнего ИК диапазона
}

\author{
Н.Н. Рубцова ${ }^{1)}$, Г.М. Борисов ${ }^{1,2)}$, В.Г. Гольдорт ${ }^{1)}$, А.А. Ковалёв ${ }^{1)}$, \\ Д.В. Ледовских ${ }^{1)}$, В.В. Преображенский ${ }^{1)}$, М.А. Путято ${ }^{1)}$, Б.Р. Семягинн ${ }^{1)}$ \\ ${ }^{I}$ Институт физики полупроводников им. А. В. Ржанова СО РАН, \\ Новосибирск, 630090, пр. Ак. Лаврентьева, 13 \\ ${ }^{2}$ Новосибирский государственный университет 630090, г. Новосибирск, ул. Пирогова, 2 \\ тел:+7 (383) 3332769, факс:+7 (383) 3332771, эл. почта: rubtsova@isp.nsc.ru
}

DOI 10.34077/RCSP2019-80

Полупроводниковые зеркала с насыщающимся поглощением [1] - ключевой элемент в получении устойчивого режима синхронизации мод лазеров. Такие зеркала обязаны обеспечивать насыщаемое поглощение заданного уровня в спектральной области усиления данного лазера; обладать быстрым просветлением и восстановлением потерь (быстродействие); обеспечивать высокий коэффициент отражения в спектральной области усиления данного лазера (широкополосность). Эти зеркала должны обладать высоким оптическим качеством (низким уровнем ненасыщаемых потерь) во всей спектральной области усиления данного лазера; быть устойчивыми к высоким интенсивностям рабочего излучения. Часто требуется способность таких оптических затворов стартовать с низкого уровня плотности энергии излучения; желательны большой срок службы зеркал, низкая стоимость, независимость от импорта. Список этих, зачастую противоречивых, требований, несомненно, будет расти по мере развития лазерной техники.

В докладе сообщается о достижениях в проектировании, исследовании и изготовлении широкополосных и быстродействующих зеркал, включающих слои квантовых ям $\mathrm{A}_{3} \mathrm{~B}_{5}$ и

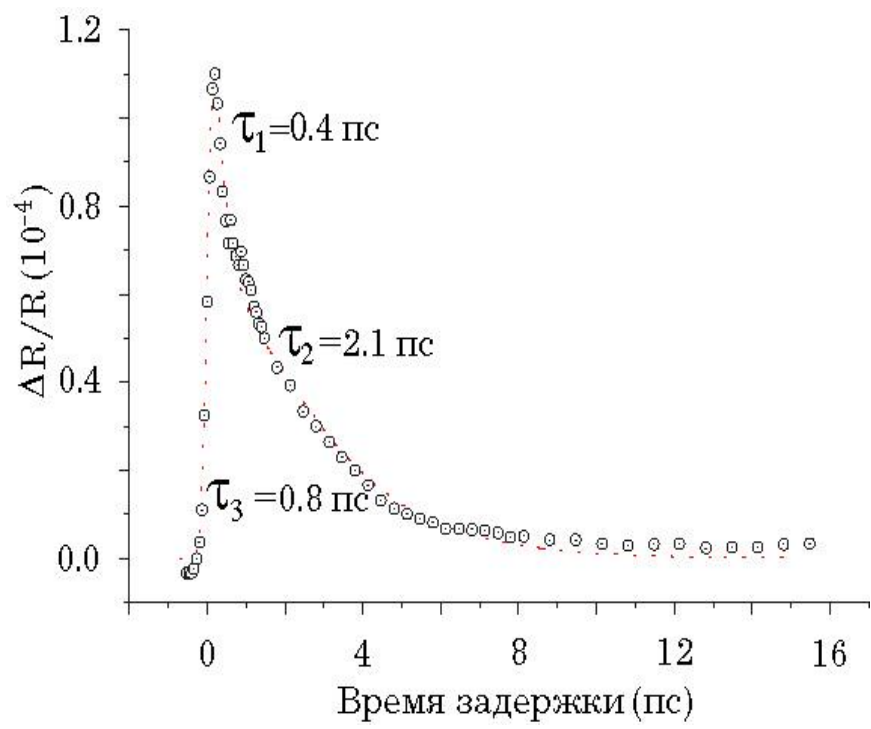
предназначенных для лазеров ближнего ИК диапазона. Рассмотрены зеркала монолитные, выращенные из полупроводниковых сверхчистых материалов типа [2-4]; зеркала с диэлектрическим отражателем и с переносом полупроводниковых структур на диэлектрик типа [5].

Последний тип зеркал показал высокое отражение в области ближнего ИК (ширина оптического стола 200 нм), уровень насыщаемых потерь до $40 \%$, регулируемых количеством квантовых ям, а также быстродействие (время восстановления работоспособности зеркала) 2 пс - время релаксации $\tau_{2}$ на рисунке. Значения времен релаксации соответствуют времени ионизации экситонов $\tau_{1}$, времени установления квазиравновесия фотогенерированных носителей заряда $\tau_{3}$ и времени электронно-дырочной рекомбинации $\tau_{2}$, определяющему быстродействие оптического затвора.

Измеренное быстродействие позволяет надеяться на получение фемтосекундных импульсов ближнего ИК диапазона с частотой следования порядка 1 ГГц.

Исследование выполнено при поддержке гранта РФФИ № 18-29-20007 и гранта РФФИ и Субъекта РФ в рамках научного проекта № 18-42-543001.

\section{Лumepamypa}

[1] U. Keller et al. // IEEE J. Selected Topics in Quantum Electronics. 1996. Vol. 2. P. 435.

[2] V.E. Kisel' et al. // Optics Letters. 2015. Vol. 40. P. 2707.

[3] A.A. Kovalyov et al. // Laser Physics Letters. 2015. Vol. 12 P. 075801.

[4] N.N. Rubtsova et al. // Laser Physics. 2016. Vol. 26. P. 025001 (6pp).

[5] Н.Н. Рубцова и др. // Прикладная фотоника. 2018. Т.5. С. 211. 